\title{
Experimental Determination of Cutting Power for Turning and Material Removal Rate for Drilling of AA 6061-T6 Using Vegetable Oils as Cutting Fluid
}

\author{
Y. M. Shashidhara and S. R. Jayaram \\ Department of Mechanical Engineering, Malnad College of Engineering, Hassan, Karnataka 573201, India \\ Correspondence should be addressed to Y. M. Shashidhara; shashi.yms@gmail.com
}

Received 27 August 2012; Revised 11 December 2012; Accepted 19 December 2012

Academic Editor: Shyam Bahadur

Copyright (C) 2013 Y. M. Shashidhara and S. R. Jayaram. This is an open access article distributed under the Creative Commons Attribution License, which permits unrestricted use, distribution, and reproduction in any medium, provided the original work is properly cited.

\begin{abstract}
The raw and modified versions of two nonedible vegetable oils, Pongam (Pogammia pinnata) and Jatropha (Jatropha curcas), and a commercially available branded mineral oil are used as straight cutting fluids for turning AA 6061 to assess cutting forces. Minimum quantity lubrication is utilized for the supply of cutting fluids. Cutting and thrust forces are measured. Cutting power is determined for various cutting speeds, depths of cut, and feed rates. Also, drilling is performed on the material to understand the material removal rate (MRR) under these oils. The performances of vegetable oils are compared to mineral oil. A noticeable reduction in cutting forces is observed under the Jatropha family of oils compared to mineral oil. Further, better material removal rate is seen under both the vegetable oils and their versions compared to under petroleum oil for the range of thrust forces.
\end{abstract}

\section{Introduction}

Cutting forces are considered as important parameters in turning operation, and they dictate the power required for machining [1]. The cutting forces influence the deformation of the workpiece machined its dimensional accuracy, chip formation, tool wear, surface roughness, and machining system stability. Higher magnitudes of forces lead to distortion in workpiece, low dimensional accuracy, faster tool wear, poor surface finish, and undesirable vibrations. Cutting forces generated mainly depend on the depth of cut, cutting speed and type of cutting fluid. As the depth of cut increases, magnitudes of forces also increase. However, increase in cutting speeds reduces the magnitude of forces. Further, cutting fluids with high lubricity, high film boiling point, and quick wetting and spreading and friction reduction at extreme pressure properties reduce cutting forces significantly [2].

Metalworking fluids are extensively used in machining operations. There are several types of metalworking fluids (MWFs), which may be used to carry out such tasks [3]. The majority of the MWFs are mineral oil-based fluids. These fluids increase productivity and the quality of manufacturing operations by cooling and lubricating during metal cutting processes [4]. The consumption of MWFs is increasing in machining industry due to their advantages. As cutting fluids are complex in their composition, they may be irritant or allergic. Even microbial toxins are generated by bacteria and fungi present, particularly in water-soluble cutting fluids [5], which are more harmful to the operators.

To overcome these challenges, various alternatives to petroleum-based MWFs are currently being explored by scientists and tribologists. Such alternatives include synthetic lubricants, solid lubricants, and vegetable-based lubricants. In general, vegetable oils are highly attractive substitutes for petroleum-based oils because they are environmentally friendly, renewable, less toxic, and readily biodegradable $[6$, 7]. Consequently, currently, vegetable-based oils are more potential candidates for the use in industry as MWFs. Many investigations are in progress to develop new bio-based cutting fluids based on various vegetable oils available around the world.

The performance of soybean, canola, palm, sunflower, and ground nut oils are evaluated as cutting fluids for machining different materials. Turning, drilling, reaming, 


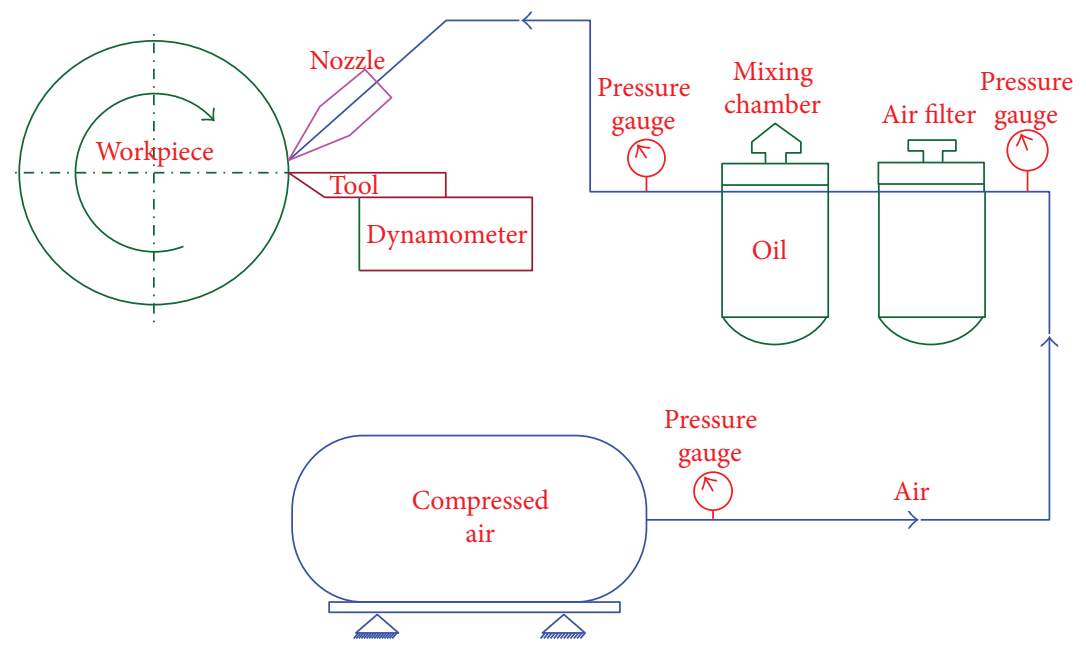

FIGURE 1: Minimum quantity lubrication circuit.

and tapping operations on austenitic stainless steel and other four materials were evaluated using vegetable-based formulations [8]. The results, on austenitic steel revealed that the cutting force under vegetable oils and esters is about $20 \%$ lower compared to reference mineral oils. Further, it is reported that about $40 \%$ increase in tool life under vegetable oils/ester modes of lubrication. Lower surface roughness, strain hardening, and thickness of the plastically deformed subsurface layer and better part accuracy are reported for a vegetable-based cutting fluid tested for reaming and tapping operations [9]. Cutting fluid formulations based on canola oil, soybean oil, and a TMP ester were made and were evaluated under tapping torque tests on 1018 cold rolled steel [10]. It is reported that all the bio-based oils exhibited about $12-14 \%$ increase in tapping torque efficiency relative to the reference soluble oil. However, Soy-based metalworking fluid had slightly higher tapping torque efficiency in the semisynthetic form compared to others.

As cutting fluids, ground nut and Shea butter oils generated lower cutting forces and coefficient friction while turning mild steel, aluminum, and copper workpieces [11]. Better surface finish is also reported under these oils. A formulated cutting fluid of canola with $8 \%$ extreme pressure additive showed comparable turning forces with mineral oils. About $61 \%$ drop in surface roughness values are reported compared to commercial mineral oil. Further, about $10 \%$ drop in tool wear is seen while turning AISI $304 \mathrm{~L}$ under canola oil [12]. Sunflower and canola-oil based cutting fluids showed better surface finish and produced lower cutting and feed forces while turning AISI $304 \mathrm{~L}$ [13]. Soybean, canola, and palm-oil based soluble cutting fluids are used for milling. About 10\% lower surface roughness values reported comparable to flank wear are seen under these formulated oils compared to mineral oil [14].

The motive of the present work is to bring out the enormous potential of vegetable oils to be used in manufacturing sector as straight cutting oils or lubricants. This has gained more importance in the light of the recent restrictions made by world leaders like OSHA, HOSH, EPA, and so forth, where they have suggested to come out with replacements for mineral oils, that are the most environmentally friendly and also are depleting. Also, there is a large consumption of cutting oils/lubricants for the manufacturing sector.

In the present study, the raw and modified versions of two nonedible vegetable oils, Pongam (Pongammia pinnata) and Jatropha (Jatropha curcass), and a commericially available branded mineral oil are used as straight cutting fluids. Turning and drilling of AA 6061 under these oils are chosen for the study. Cutting and thrust forces are measured for various cutting speeds, depth of cut, and feed. Cutting power is determined for turning the material. Further, drilling is performed on the material to assess the material removal rate (MRR) under these oils for various thrust forces. The results obtained are compared to the results under mineral oil.

\section{Experiments}

2.1. Oil Modification. The raw vegetable oils have certain limitations like low thermooxidative stability [15]. These problems are addressed by various methods, namely, reformulation of additives, chemical modifications, and genetic modification of the oil seed [16]. In the present work, chemical modification methods such as epoxidation [17] and transesterification [18] are used to modify the structure of two raw oils. After the modifications, their polyunsaturated $\mathrm{C}=\mathrm{C}$ bonds are eliminated in the oil structure, and the thermooxidative stability, the resistance of a lubricant to molecular breakdown or molecular rearrangement at elevated temperature in the absence/presence of oxygen, is enhanced.

Pongam raw oil (PRO) is modified into Pongam methyl ester (PME) and epoxidized Pongam raw oil (EPRO). Similarly, Jatropha raw oil (JRO) is altered to Jatropha methyl ester (JME) and epoxidized Jatropha raw oil (EJRO). Further, Pongam methyl ester (PME) and Jatropha methyl ester (JME) are modified into epoxidized Pongam methyl ester (EPME) and epoxidized Jatropha methyl ester (EJME), respectively. 


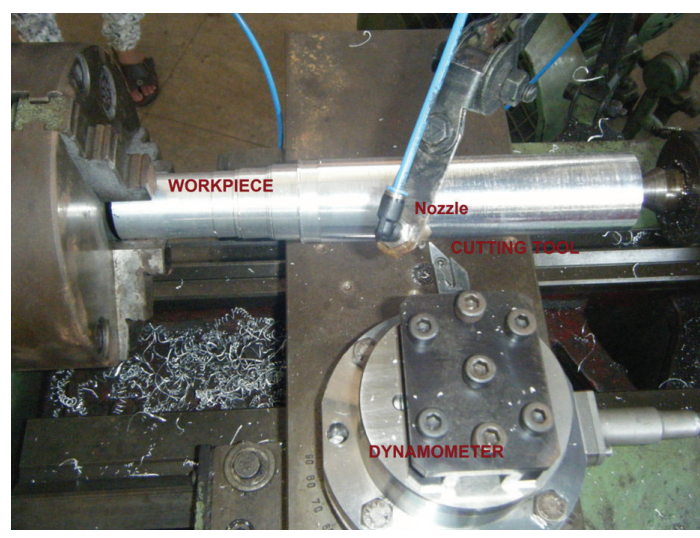

FIGURE 2: Experimental setup.

Turning (Figure 2) is carried out on AA 6061 using a lathe of $7.5 \mathrm{~kW}$ capacity. Cemented carbide tool with $0^{\circ}$ rake angle and $14^{\circ}$ clearance angles is utilised for cutting operation. Minimum quantity lubrication (MQL) method is adopted to supply the cutting fluid.

The MQL circuit (Figure 1) consists of an air compressor, mixing chamber, nozzle, and three pressure gauges. A nozzle of $2 \mathrm{~mm}$ is used for the experiments. Compressed air at $3 \mathrm{bar}$ pressure is mixed with oil in the mixing chamber. The mist formed from the chamber is then fed in between cutting tool and workpiece through the nozzle.

Experiments are conducted under mineral, raw, and modified versions of the two vegetable oils as straight cutting oils for various cutting speeds $(60,90$, and $140 \mathrm{~m} / \mathrm{min})$, depths of cuts $(0.5,1.0$, and $1.5 \mathrm{~mm})$, and feeds of $0.1 \mathrm{~mm} / \mathrm{rev}$, $0.18 \mathrm{~mm} / \mathrm{rev}$, and $0.25 \mathrm{~mm} / \mathrm{rev}$. The cutting forces are measured using Kistler lathe tool dynamometer (Figure 2). The forces are used to determine cutting power for turning.

Drilling is performed on AA 6061 sheets using HSS drill tool. Experiments are conducted for a constant spindle speed of $2625 \mathrm{rpm}$ (maximum available speed). The time for drilling a hole is noted for thrust forces of $112 \mathrm{~N}, 138 \mathrm{~N}, 172 \mathrm{~N}$, and $182 \mathrm{~N}$ under mineral, raw, and modified versions of the two vegetable oils as cutting fluids. The thrust forces are measured using a drill tool dynamometer.

\section{Results and Discussion}

3.1. Cutting Power. Cutting power required for machining provides the necessary input to understand the capacity of the drive. Cutting fluid with better lubrication capabilities reduces the power requirements.

Experimentally measured cutting forces for various cutting speeds, depths of cut, and feed are used to calculate the cutting power for turning AA 6061 under mineral and different vegetable oils and their versions (Table 1). Further, the results are also represented as three-dimensional pictures. The desirable conditions for turning AA 6061 under vegetable oil (raw and modified) are compared to mineral oil. An expected linear raise in cutting power is seen with an increase

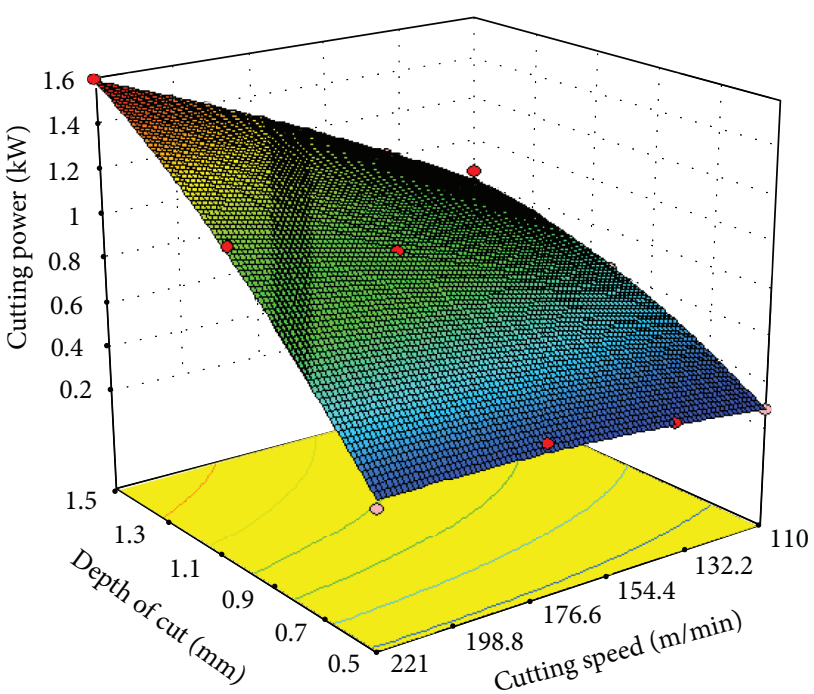

FIGURE 3: Variation of cutting power with cutting speed and depth of cut under MRO.

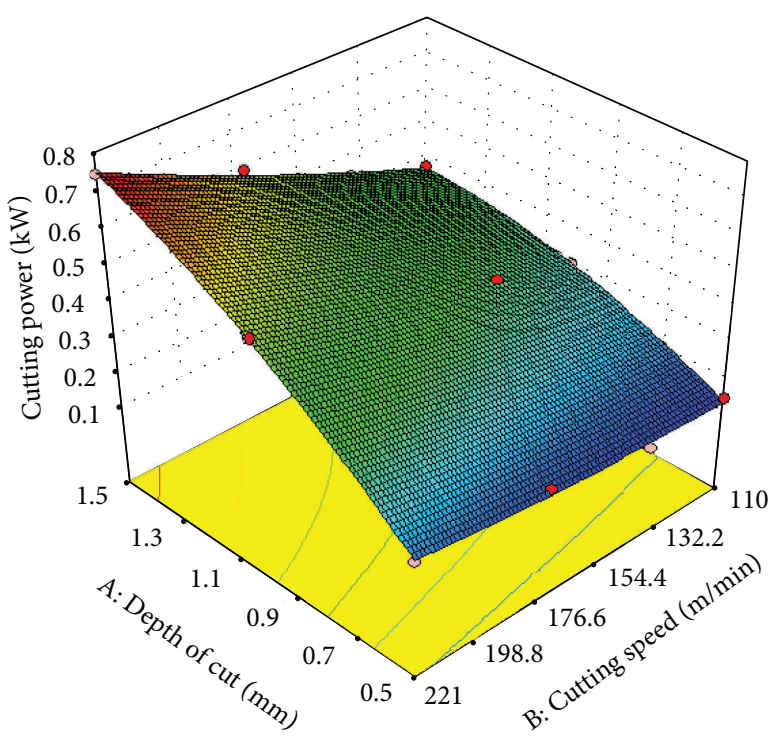

FIGURE 4: Variation of cutting power with cutting speed and depth of cut under PRO.

in cutting speeds and depths of cut [19]. Increase in cutting power is marginal for increase in cutting speed. However, it is significant with higher depths of cuts.

Figure 3 shows the cutting power distribution. Figure 3 through to Figure 6 are the plots with maximum drop in cutting power for Pongam and its versions. Figure 6 through to Figure 8 are for Jatropha and its versions.

3.1.1. Comparison of Pongam with Mineral Oil. Pongam raw oil and its modified versions show lower cutting power compared to mineral oil for the complete range of cutting speeds, depths of cut, and feed. Around 25\% drop in cutting power for the feed $0.1 \mathrm{~mm} / \mathrm{rev}$ and $0.5 \mathrm{~mm}$ depth of cut is 
TABLE 1: Cutting power generated under various oils for different feed, depths of cut, and cutting speeds.

\begin{tabular}{|c|c|c|c|c|c|c|c|c|}
\hline \multirow{2}{*}{ Cutting speed $(\mathrm{m} / \mathrm{min})$} & \multicolumn{7}{|c|}{ Cutting power $(\mathrm{kW})$} & \multirow{2}{*}{ Cutting conditions } \\
\hline & MRO & PRO & EPRO & EPME & JRO & EJRO & EJME & \\
\hline 110 & 0.137 & 0.137 & 0.137 & 0.128 & 0.146 & 0.137 & 0.137 & \multirow{4}{*}{$\begin{array}{l}{ }^{*} F=0.1 \mathrm{~mm} / \mathrm{rev} \\
{ }^{*} \mathrm{DOC}=0.5 \mathrm{~mm}\end{array}$} \\
\hline 138 & 0.172 & 0.115 & 0.161 & 0.138 & 0.184 & 0.161 & 0.161 & \\
\hline 175 & 0.219 & 0.175 & 0.204 & 0.175 & 0.204 & 0.219 & 0.219 & \\
\hline 221 & 0.257 & 0.202 & 0.239 & 0.202 & 0.220 & 0.257 & 0.276 & \\
\hline 110 & 0.216 & 0.210 & 0.238 & 0.219 & 0.210 & 0.210 & 0.192 & \multirow{5}{*}{$\begin{array}{l}F=0.18 \mathrm{~mm} / \mathrm{rev} \\
\mathrm{DOC}=0.5 \mathrm{~mm}\end{array}$} \\
\hline 138 & 0.259 & 0.264 & 0.264 & 0.264 & 0.253 & 0.259 & 0.230 & \\
\hline 175 & 0.327 & 0.321 & 0.306 & 0.321 & 0.321 & 0.327 & 0.289 & \\
\hline 221 & 0.404 & 0.404 & 0.368 & 0.386 & 0.386 & 0.386 & 0.349 & \\
\hline 110 & 0.284 & 0.293 & 0.284 & 0.274 & 0.274 & 0.265 & 0.265 & \\
\hline 138 & 0.351 & 0.333 & 0.345 & 0.333 & 0.333 & 0.322 & 0.322 & \multirow{3}{*}{$\begin{array}{l}F=0.25 \mathrm{~mm} / \mathrm{rev} \\
\mathrm{DOC}=0.5 \mathrm{~mm}\end{array}$} \\
\hline 175 & 0.438 & 0.394 & 0.423 & 0.408 & 0.408 & 0.408 & 0.394 & \\
\hline 221 & 0.533 & 0.478 & 0.515 & 0.478 & 0.507 & 0.496 & 0.331 & \\
\hline 110 & 0.293 & 0.293 & 0.293 & 0.274 & 0.302 & 0.293 & 0.284 & \multirow{4}{*}{$\begin{array}{l}F=0.1 \mathrm{~mm} / \mathrm{rev} \\
\mathrm{DOC}=1 \mathrm{~mm}\end{array}$} \\
\hline 138 & 0.363 & 0.356 & 0.333 & 0.333 & 0.356 & 0.356 & 0.333 & \\
\hline 175 & 0.452 & 0.408 & 0.408 & 0.408 & 0.438 & 0.438 & 0.408 & \\
\hline 221 & 0.552 & 0.533 & 0.473 & 0.500 & 0.515 & 0.515 & 0.515 & \\
\hline 110 & 0.485 & 0.467 & 0.549 & 0.458 & 0.485 & 0.458 & 0.430 & \multirow{4}{*}{$\begin{array}{l}F=0.18 \mathrm{~mm} / \mathrm{rev} \\
\mathrm{DOC}=1 \mathrm{~mm}\end{array}$} \\
\hline 138 & 0.598 & 0.575 & 0.540 & 0.563 & 0.586 & 0.517 & 0.529 & \\
\hline 175 & 0.715 & 0.686 & 0.671 & 0.700 & 0.730 & 0.642 & 0.642 & \\
\hline 221 & 0.846 & 0.828 & 0.791 & 0.846 & 0.846 & 0.791 & 0.791 & \\
\hline 110 & 0.623 & 0.586 & 0.641 & 0.604 & 0.623 & 0.531 & 0.623 & \multirow{4}{*}{$\begin{array}{l}F=0.25 \mathrm{~mm} / \mathrm{rev} \\
\mathrm{DOC}=1 \mathrm{~mm}\end{array}$} \\
\hline 138 & 0.736 & 0.724 & 0.736 & 0.736 & 0.736 & 0.655 & 0.759 & \\
\hline 175 & 0.919 & 0.846 & 0.846 & 0.846 & 0.744 & 0.817 & 0.934 & \\
\hline 221 & 1.104 & 1.030 & 1.030 & 1.030 & 0.920 & 0.920 & 1.104 & \\
\hline 110 & 0.412 & 0.366 & 0.421 & 0.384 & 0.430 & 0.412 & 0.412 & \multirow{4}{*}{$\begin{array}{l}F=0.1 \mathrm{~mm} / \mathrm{rev} \\
\mathrm{DOC}=1.5 \mathrm{~mm}\end{array}$} \\
\hline 138 & 0.494 & 0.437 & 0.506 & 0.506 & 0.506 & 0.494 & 0.506 & \\
\hline 175 & 0.613 & 0.584 & 0.627 & 0.627 & 0.613 & 0.569 & 0.598 & \\
\hline 221 & 0.736 & 0.736 & 0.809 & 0.901 & 0.736 & 0.736 & 0.736 & \\
\hline 110 & 0.632 & 0.650 & 0.641 & 0.669 & 0.669 & 0.650 & 0.641 & \multirow{4}{*}{$\begin{array}{l}F=0.18 \mathrm{~mm} / \mathrm{rev} \\
\mathrm{DOC}=1.5 \mathrm{~mm}\end{array}$} \\
\hline 138 & 0.782 & 0.782 & 0.770 & 0.805 & 0.782 & 0.782 & 0.782 & \\
\hline 175 & 0.934 & 0.919 & 0.949 & 0.963 & 0.919 & 0.949 & 0.919 & \\
\hline 221 & 1.159 & 1.140 & 1.140 & 1.177 & 1.122 & 1.177 & 1.140 & \\
\hline 110 & 0.852 & 0.834 & 0.760 & 0.870 & 0.779 & 0.806 & 0.639 & \multirow{4}{*}{$\begin{array}{l}F=0.25 \mathrm{~mm} / \mathrm{rev} \\
\mathrm{DOC}=1.5 \mathrm{~mm}\end{array}$} \\
\hline 138 & 0.966 & 0.989 & 0.751 & 0.824 & 0.724 & 0.797 & 0.724 & \\
\hline 175 & 1.197 & 1.197 & 1.416 & 1.126 & 1.109 & 1.211 & 0.898 & \\
\hline 221 & 1.453 & 1.453 & 1.398 & 1.527 & 1.343 & 1.435 & 1.051 & \\
\hline
\end{tabular}

${ }^{*} F$ : Feed, ${ }^{*}$ DOC: Depth of Cut.

seen under PRO (Figures 3 and 4). This drop is the maximum compared to other combinations of feed and depths of cut. EPRO exhibits maximum of $20 \%$ lower cutting power for $0.1 \mathrm{~mm} / \mathrm{rev}$ of feed and $1 \mathrm{~mm}$ depths of cut compared to MRO (Figure 5). About $28 \%$ drop in cutting power for feeds $0.1 \mathrm{~mm} / \mathrm{rev}$ and $0.5 \mathrm{~mm}$ depth of cut is seen under EPME compared to petroleum oil (Figure 6). On the other hand, a marginal increase in cutting power is seen for higher feed and depths of cut.
3.1.2. Comparison of Jatropha with Mineral Oil. Similar to Pongam family of oils, Jatropha raw oil and its modified versions also show lower cutting power compared to mineral oil for the complete range of cutting speeds, depths of cut, and feeds. A maximum of 30\% drop in cutting power is seen under JRO for the feed of $0.25 \mathrm{~mm} / \mathrm{rev}$ and depth of cut $1 \mathrm{~mm}$ compared to mineral oil (Figure 7). Further, 10\% constant drop in cutting power is observed for the other two depths of cut and feeds compared to petroleum oil. 


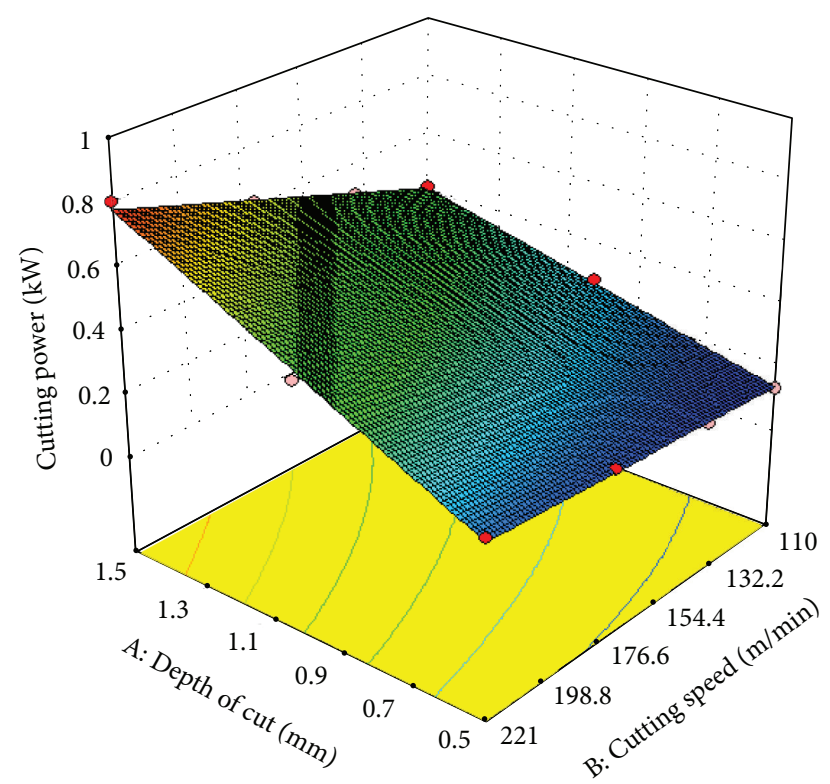

FIGURE 5: Variation of cutting power with cutting speed and depth of cut under EPRO.

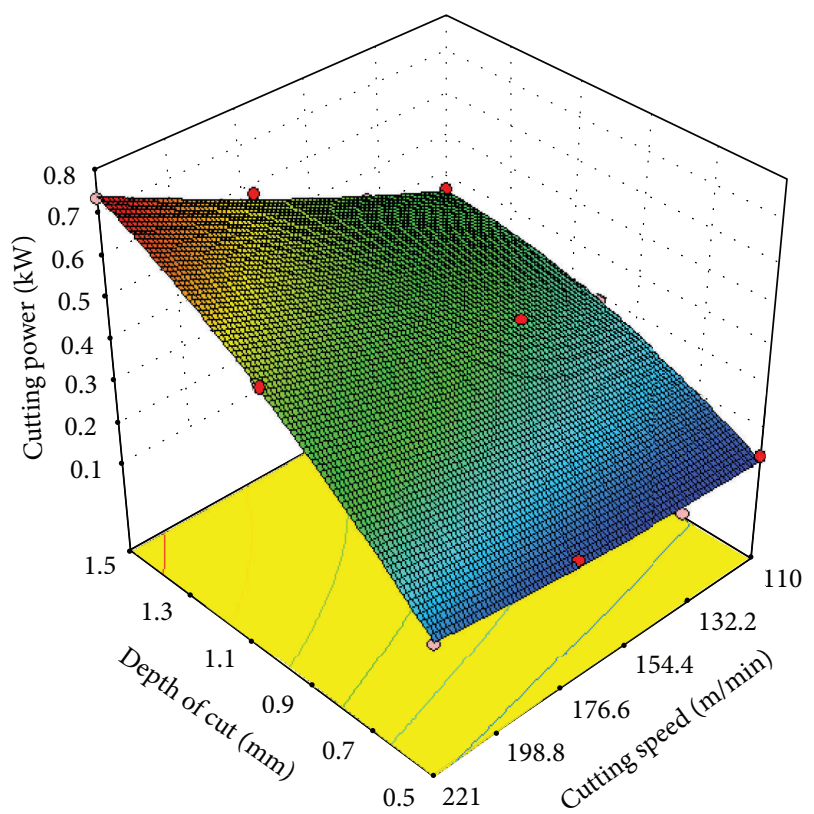

FIGURE 6: Variation of cutting power with cutting speed and depth of cut under EPME.

About 20\% reduction in cutting power under EJRO for feed $0.25 \mathrm{~mm} / \mathrm{rev}$ and depth of cut $1 \mathrm{~mm}$ compared to MRO (Figure 8). Under EJME, about 25\% reduction in cutting power is seen for all the depths of cut and feed range except for feed $0.25 \mathrm{~mm} / \mathrm{rev}$ and depth of cut $1.5 \mathrm{~mm}$ (Figure 9).

The drop in cutting power for turning under all the types of vegetable oils can be attributed to their polar nature and viscosity properties. Significant power reductions under vegetable oils can be due to the fact that, the thin surface film that develops in boundary lubrication is formed by

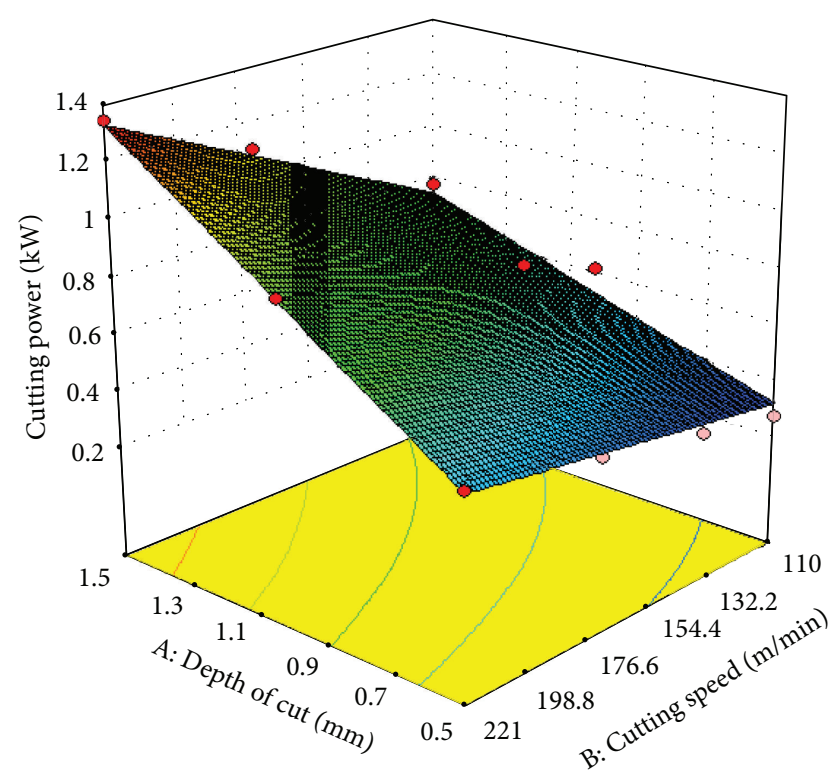

FIgURE 7: Variation of cutting power with cutting speed and depth of cut under JRO.

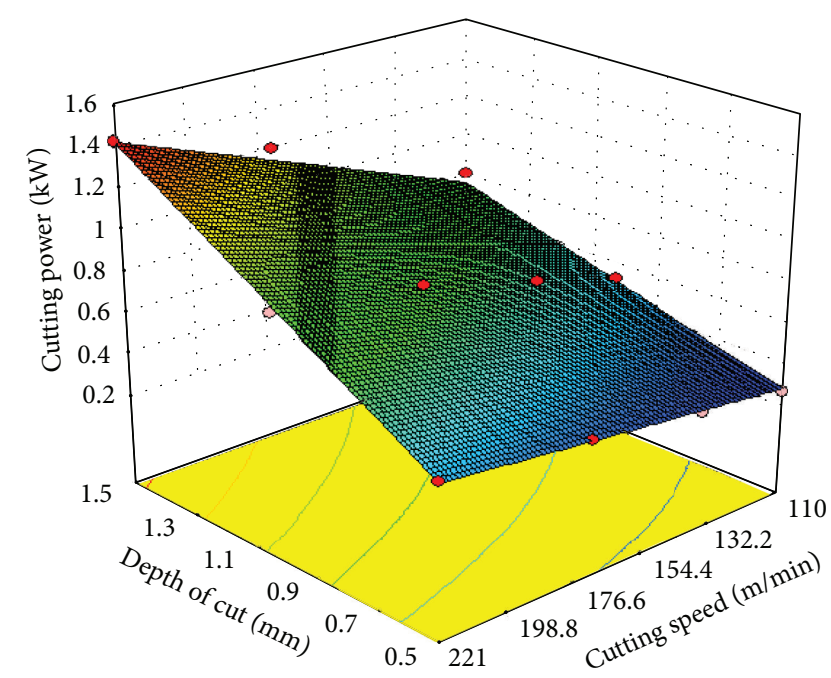

FIgURE 8: Variation of cutting power with cutting speed and depth of cut under EJRO.

the adsorption of polar compounds at the metal surface of the mating pair or by chemical reaction of the lubricant at the surface. Since, boundary lubrication by fatty acids is associated with the adsorption of the acid by dipolar attraction at the surface, they are capable of reducing the friction between the surfaces [20]. Jatropha versions exhibit noticeable power reductions at very high cutting speeds and depths of cut. This is due to high Oleic acid content [21] in the oil, higher viscosity index, and higher thermal conductivity of Jatropha compared to Pongam as well as mineral oil.

3.2. Drilling. In this segment, material removal rate under the two vegetable oils and their modified versions are analysed 


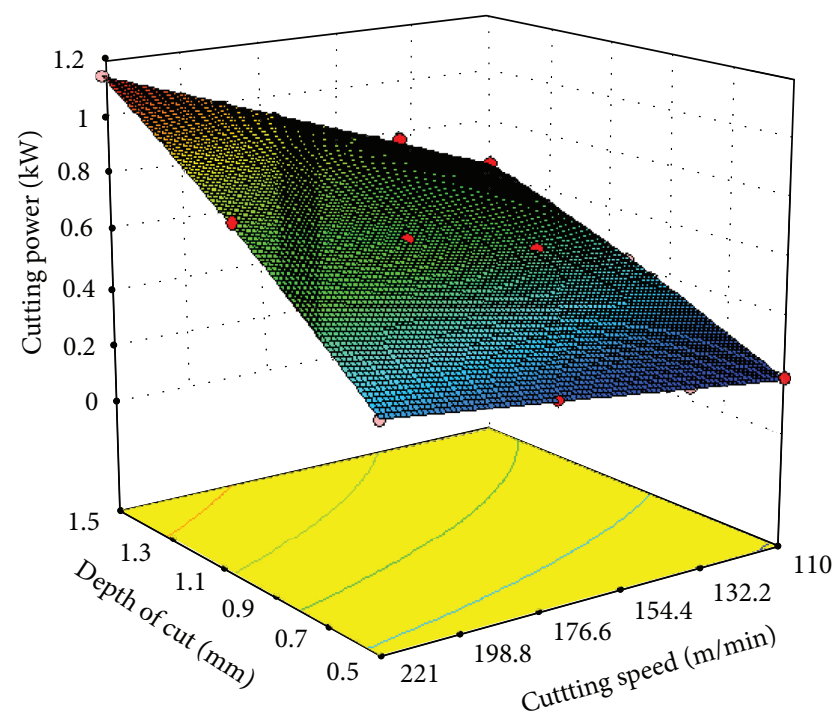

FIGURE 9: Variation of cutting power with cutting speed and depth of cut under EJME.

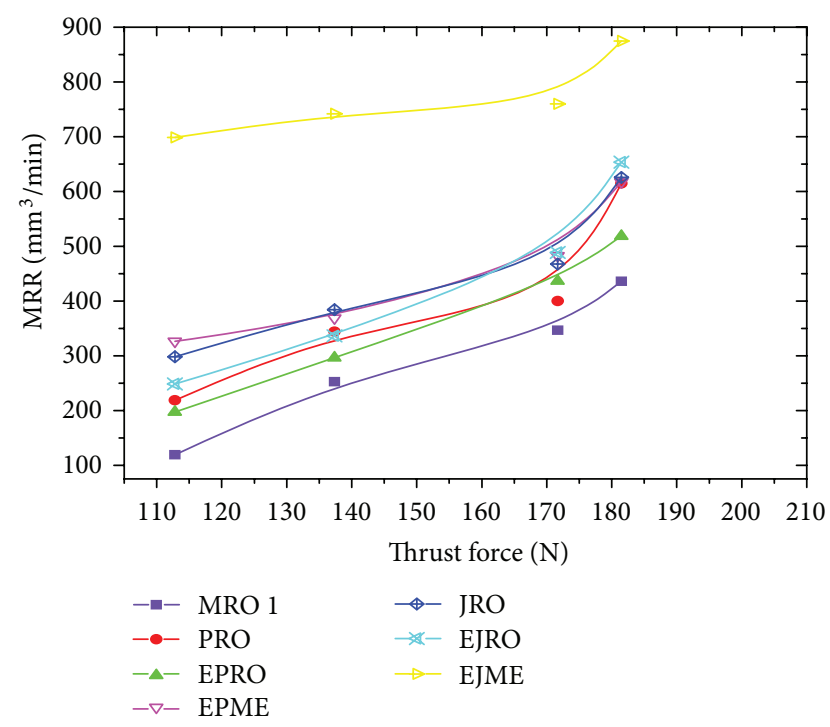

FIGURE 10: Variation of material removal rate with thrust force for various oils.

and compared to mineral oil for the range of thrust force $(112 \mathrm{~N}$ to $180 \mathrm{~N})$.

3.2.1. Material Removal Rate (MRR). It is the volume of material removed/drilled out from the workpiece per unit time. It depends on the material, thrust force, feed, cutting speed, and cutting fluid. In drilling, high material removal rate and long drill life are essential to increase productivity. To achieve the desired MRR, high feed per revolution and cutting speed are required [22]. Further, a cutting fluid with good lubrication property produces higher rate of material removal.

Higher material removal is seen under both the vegetable oils and their versions compared to under mineral oil for

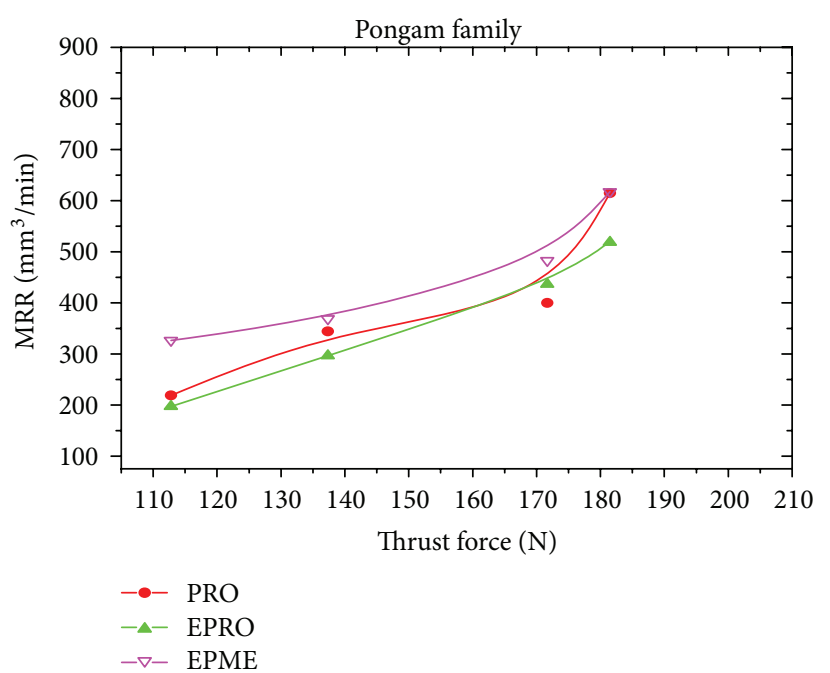

FIGURE 11: Variation of material removal rate with thrust force for Pongam family.

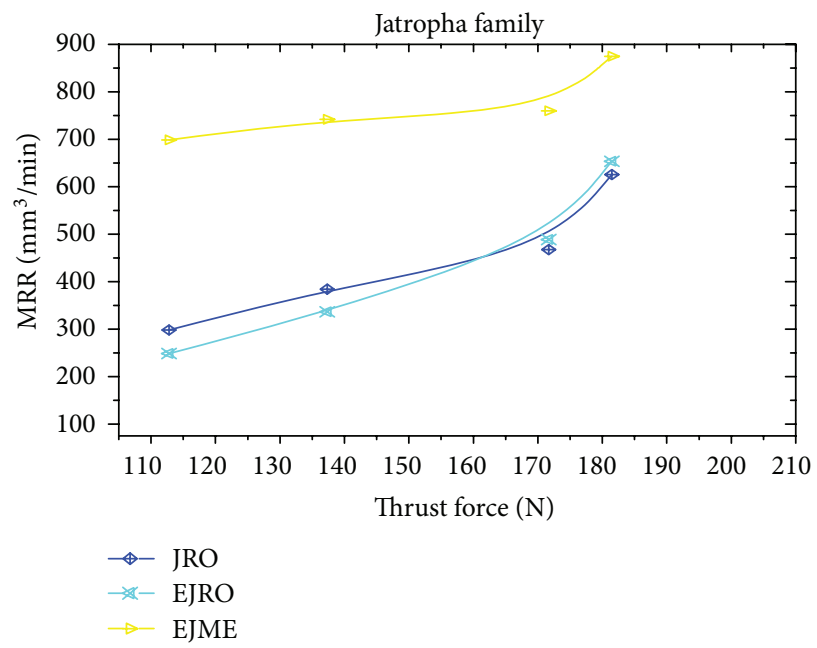

FIGURE 12: Variation of material removal rate with thrust force for Jatropha family.

the range of thrust forces. This could be clearly seen from Figure 10 that, say, for the thrust force of $172 \mathrm{~N}$, about $20 \%$ increase in MRR is observed under Pongam family (Figure 11) compared to under mineral oil. Similarly, under Jatropha family, about $40 \%$ increase in MRR is noticed. Interestingly, EJME offered the best MRR compared to all other oils tested with $50 \%$ increased MRR (Figure 12). It is attributed to the better lubrication capability of the oil.

The epoxidized methyl ester versions of both oils are seem to be the better cutting fluid to drilling AA 6061 as both of them show higher material removal property.

\section{Conclusions}

Pongam and Jatropha oils and their versions are better cutting fluids in terms of lower cutting forces and power 
for turning AA 6061 compared to mineral oil. The drop in power under vegetable oils is predominant at very low and very high cutting speeds compared to mineral oil. Among the two vegetable oils, Jatropha versions show noticeable power reductions at higher cutting speeds and depths of cut. Specifically, EJME offers a better cutting fluid for turning AA 6061.

\section{References}

[1] B. Fnides, H. Aouici, and M. A. Yallese, "Cutting forces and surface roughness in hard turning of hot work steel X38CrMoV51 using mixed ceramic," Mechanika, vol. 70, no. 2, pp. 73-77, 2008.

[2] S. Kalpakjian and R. S. Steven, Manufacturing Engineering and Technology, Pearson Education, 4th edition.

[3] H. S. Abdalla and S. Patel, "The performance and oxidation stability of sustainable metalworking fluid derived from vegetable extracts," Proceedings of the Institution of Mechanical Engineers B, vol. 220, no. 12, pp. 2027-2040, 2006.

[4] J. B. Zimmerman, A. F. Clarens, K. F. Hayes, and S. J. Skerlos, "Design of hard water stable emulsifier systems for petroleumand bio-based semi-synthetic metalworking fluids," Environmental Science and Technology, vol. 37, no. 23, pp. 5278-5288, 2003.

[5] A. Zeman, A. Sprengel, D. Niedermeier, and M. Späth, "Biodegradable lubricants-studies on thermo-oxidation of metal-working and hydraulic fluids by differential scanning calorimetry (DSC)," Thermochimica Acta C, vol. 268, pp. 9-15, 1995.

[6] T. Norrby, "Environmentally adapted lubricants-where are the opportunities?" Industrial Lubrication and Tribology, vol. 55, no. 6, pp. 268-274, 2003.

[7] M. T. Siniawski, N. Saniei, B. Adhikari, and L. A. Doezema, "Influence of fatty acid composition on the tribological performance of two vegetable-based lubricants," Journal of Synthetic Lubrication, vol. 24, no. 2, pp. 101-110, 2007.

[8] L. De Chiffre and W. Belluco, "Investigations of cutting fluid performance using different machining operations," Lubrication Engineering, vol. 58, no. 10, pp. 22-29, 2002.

[9] W. Belluco and L. De Chiffre, "Performance evaluation of vegetable-based oils in drilling austenitic stainless steel," Journal of Materials Processing Technology, vol. 148, no. 2, pp. 171-176, 2004.

[10] F. C. Andres, "Experimental comparison of vegetable and petroleum base oils in Metal working fluids using the tapping torque test," in Proceedings of the Japan-USA Symposium on Flexible Automation, Denver, Colo, USA, 2004.

[11] S. J. Ojolo, M. O. H. Amuda, O. Y. Ogunmola, and C. U. Ononiwu, "Experimental determination of the effect of some straight biological oils on cutting force during cylindrical turning," Revista Materia, vol. 13, no. 4, pp. 650-663, 2008.

[12] B. Ozcelik, E. Kuram, M. H. Cetin, and E. Demirbas, "Experimental investigations of vegetable based cutting fluids with extreme pressure during turning of AISI 304L," Tribology International, vol. 44, no. 12, pp. 1864-1871, 2011.

[13] H. Cetin, B. Ozcelik, E. Kuram, and E. Demirbas, "Evaluation of vegetable based cutting fluids with extreme pressure and cutting parameters in turning of AISI 304L by Taguchi method," Journal of Cleaner Production, vol. 19, no. 17-18, pp. 2049-2056, 2011.
[14] T. S. Lee and H. B. Choong, "An investigation on green machining: cutting process characteristics of organic metalworking fluid," Advanced Materials Research, vol. 230-232, pp. 809-813, 2011.

[15] B. K. Sharma, A. Adhvaryu, and S. Z. Erhan, "Friction and wear behavior of thioether hydroxy vegetable oil," Tribology International, vol. 42, no. 2, pp. 353-358, 2009.

[16] N. J. Fox and G. W. Stachowiak, "Vegetable oil-based lubricantsA review of oxidation," Tribology International, vol. 40, no. 7, pp. 1035-1046, 2007.

[17] X. Wu, X. Zhang, S. Yang, H. Chen, and D. Wang, “The study of Epoxidised Rapeseed oil used as a Potential Biodegradable Lubricant," Journal of the American Oil Chemists' Society, vol. 77, no. 5, pp. 561-563, 2000.

[18] R. A. Holser, "Transesterification of epoxidized soybean oil to prepare epoxy methyl esters," Industrial Crops and Products, vol. 27, no. 1, pp. 130-132, 2008.

[19] A. Aggarwal, H. Singh, P. Kumar, and M. Singh, "Optimizing power consumption for $\mathrm{CNC}$ turned parts using response surface methodology and Taguchi's technique-A comparative analysis," Journal of Materials Processing Technology, vol. 200, no. 1-3, pp. 373-384, 2008.

[20] S. Bhuyan, S. Sundararajan, L. Yao, E. G. Hammond, and T. Wang, "Boundary lubrication properties of lipid-based compounds evaluated using microtribological methods," Tribology Letters, vol. 22, no. 2, pp. 167-172, 2006.

[21] Y. M. Shashidhara and S. R. Jayaram, "Vegetable oils as a potential cutting fluid-an evolution," Tribology International, vol. 43, no. 5-6, pp. 1073-1081, 2010.

[22] R. Li and A. J. Shih, "Spiral point drill temperature and stress in high-throughput drilling of titanium," International Journal of Machine Tools and Manufacture, vol. 47, no. 12-13, pp. 2005-2017, 2007. 

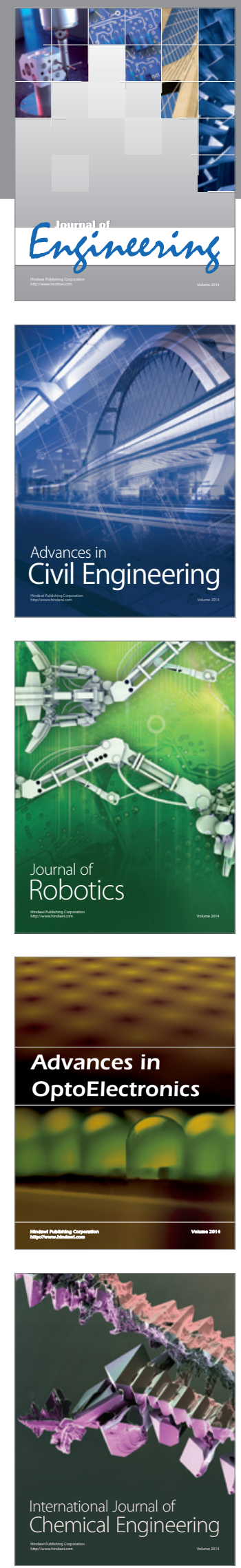

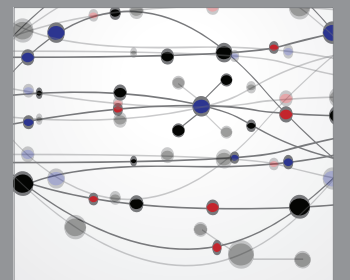

The Scientific World Journal
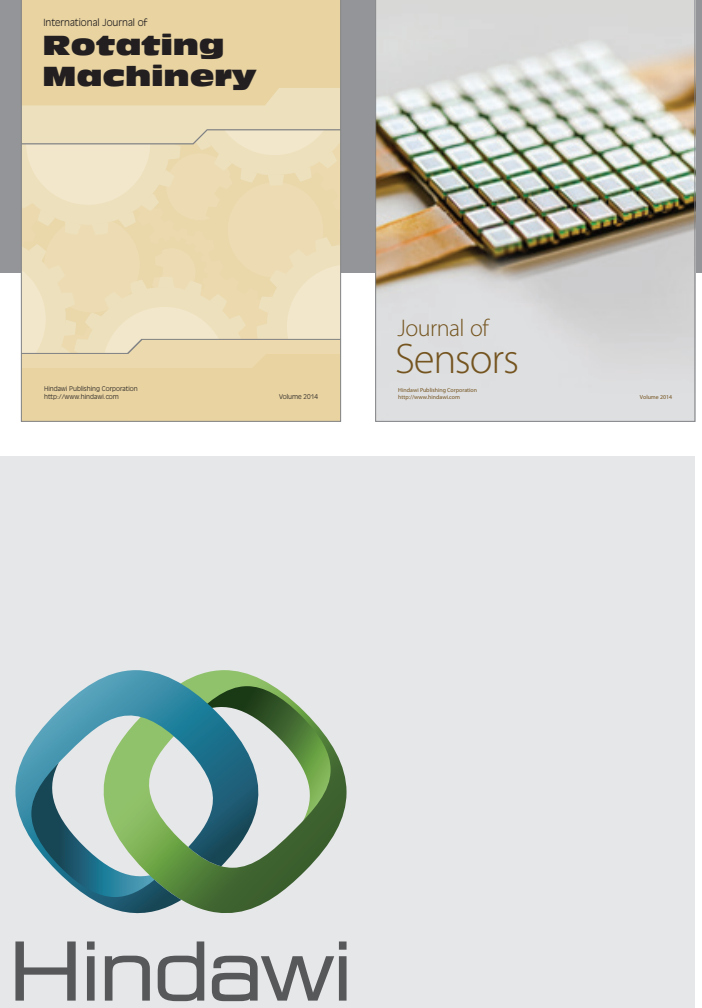

Submit your manuscripts at http://www.hindawi.com
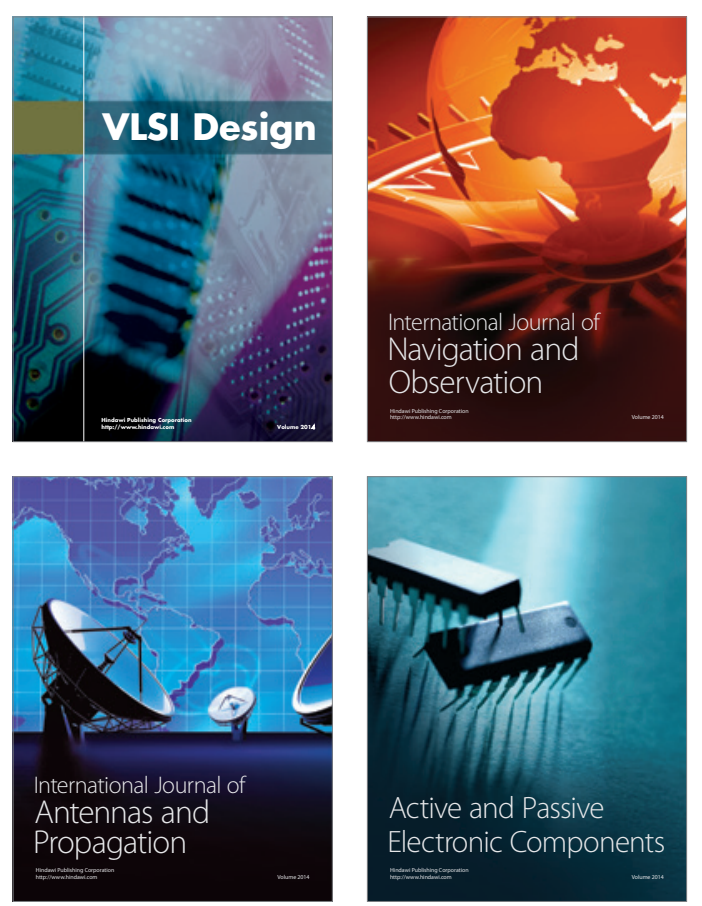
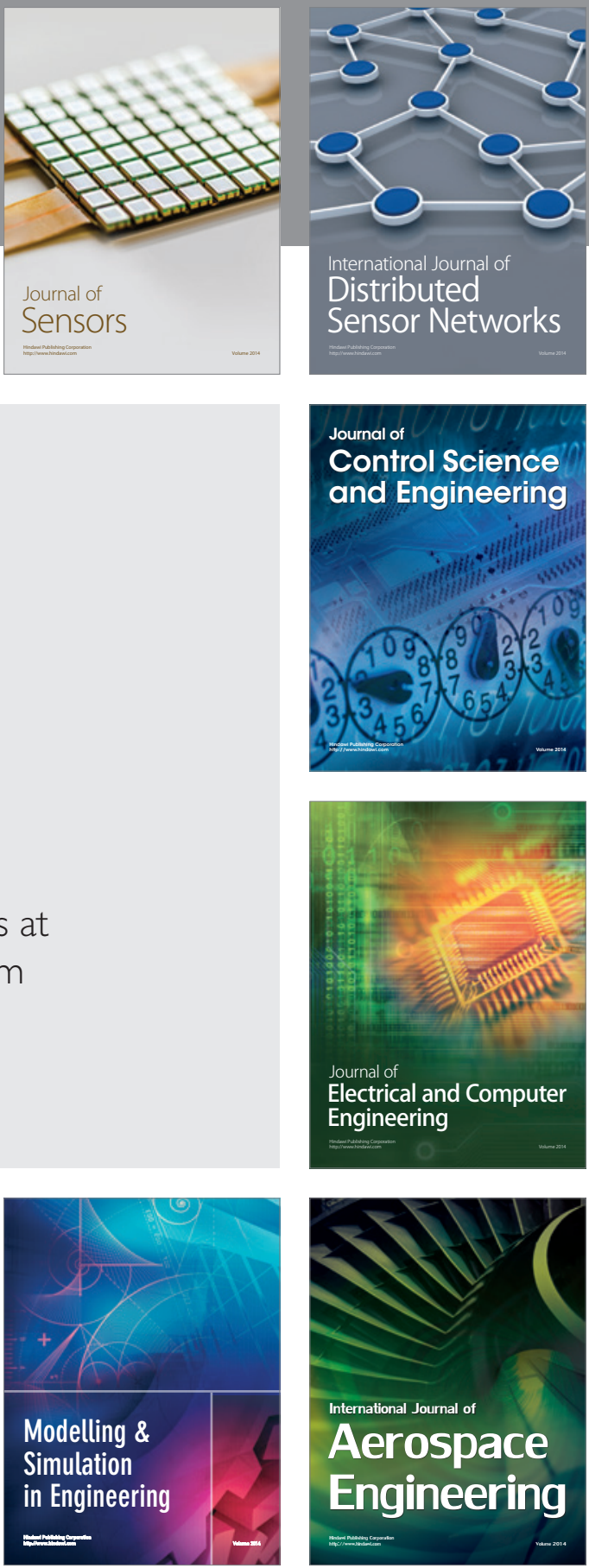

Journal of

Control Science

and Engineering
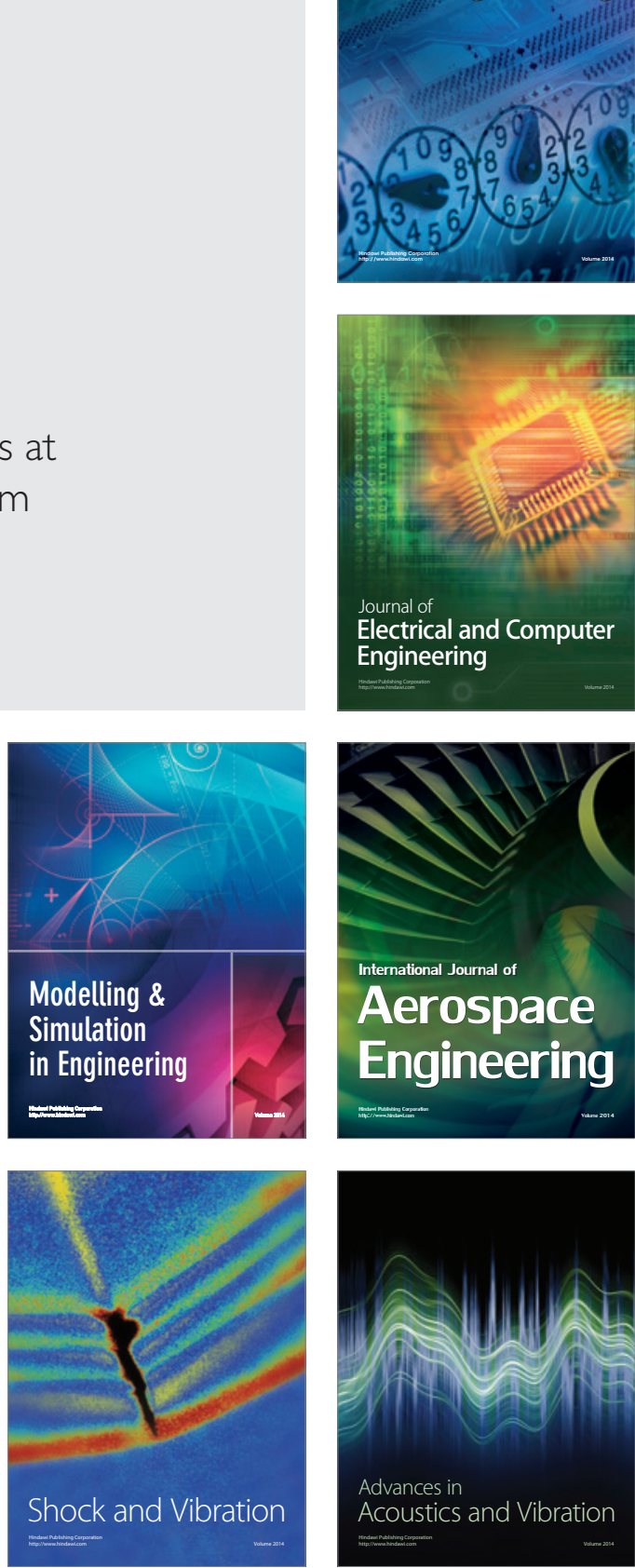